\title{
Linear Programming Application in optimal allocation of Buses to Inter and Intra State Routes from Katsina State Transport Authority Service, Nigeria
}

\author{
Abdullahi, I. ${ }^{1, *}$, Usman, S. ${ }^{2}$, Aliyu S. I. ${ }^{3}$, \\ Yusuf, H. B ${ }^{4}$, Kabir, G. I. ${ }^{5}$, Agaie, B. G. ${ }^{6}$ \\ 1,2,3,5,6 Federal University Dutse (FUD), \\ P.M.B 7156 Dutse, Jigawa State, Nigeria \\ ${ }^{4}$ Department of Mathematics, \\ Nigerian Army University Biu, \\ P.M.B 1500 Biu, Borno State, Nigeria \\ Email: iabdullahi94@gmail.com,
}

\begin{abstract}
In this paper, we study Linear Programming application in optimal allocation of Buses to inter and intra state routes from Katsina State transport authority services to maximize profit and boost the state's internally generated revenue. The problem was formulated from the data collected at their headquarters and by taking into consideration all the constraints. The TORA (a software for finding solution to linear programming problems) was used to obtained the solution to the model which yielded the maximum objective value of $¥ 729,578$ daily after 16 iterations. This gives better result when compared to the current initiative schedule by the authority that yields \$584, 652 per day. By the recommendation schedule, the State will be getting additional $\$ 144,926.00$ daily which translates to $24.8 \%$ daily profit increase and over $\$ 4,000,000.00$ monthly when implemented.
\end{abstract}

Keywords: KTSTA, TORA, Linear Programming, Transport Services, Sensitivity analysis, Objectives Value.

\section{INTRODUCTION}

Linear Programming (LP), also called Linear Optimization is a method to achieve the best outcome (such as maximum profit or minimum cost) in the mathematical model whose requirements are represented by linear relationships (Lucey, 2002). Linear programming is a special case of mathematical programming (also known as mathematical optimization) (Kanu et al, 2014).

More formally, linear programming is a technique for the optimization of a linear objective function, subject to linear equality and linear inequality constraints. Its feasible region is a convex polytope, which is a set defined as the intersection of finitely many half spaces, each of which is defined by a linear inequality. Its objective is a real valued affine (linear) function defined on this polyhedron. A linear programming algorithm finds a point in the polytope 
where this function has the smallest (or largest) value if such a point exists ( $\mathrm{Ng}$ et al, 2018, Salimifard et al, 2012).

Salimifard et al, (2012) stated that Linear programming contributed in attaining the optimum use of productive resources. It shows how a decision-maker can employ the productive factors effectively by selection and distribution of these resources. Linear programming approach brings quality life because of good decisions made. Linear programming approaches made possible and practical solutions since there could be other constraints operating outside the problem that must be taken into consideration. Production of many units does not translate to all been sold. Hence, necessary modification of its mathematical solution is required for the sake of convenience to the decision-maker (Bertsimas \& Tsitsiklis, 1997, Fang \& Puthenpura 1993).

However, according to Lieberman (2001) Linear programming major application is to problems where the constraints and the objective functions are linear. Factors such as uncertainty, weather conditions etc. are not taken into consideration. There is restriction to linear objective function (Hiller et al, 1995).

Linear programs are problems that can be expressed in canonical forms as Optimize (Max or Min) $Z=c_{1} x_{1}+c_{2} x_{2}+\ldots+c_{n} x_{n}$

Subject to $a_{11} x_{1}+a_{12} x_{2}+\ldots+a_{1 n} x_{n} \leq b_{1}$ (for maximization)

$$
\begin{aligned}
& a_{21} x_{2}+a_{22} x_{2}+\ldots+a_{2 n} x_{n} \geq b_{2} \text { (for minimization) } \\
& a_{31} x_{1}+a_{32} x_{2}+\ldots+a_{3 n} x_{n}=b_{3} \text { (for equality) } \\
& \ldots \quad \ldots \quad \ldots \\
& a_{1 m} x_{1}+a_{2 m} x_{2}+\ldots+a_{m n} x_{n}[\leq \quad \text { Or } \geq]{ }_{m}{ }_{m} \\
& x_{i} \geq 0, \forall i=1,2,3, \ldots, n \quad \text { (Non negativity restriction) }
\end{aligned}
$$

\section{Brief History of Katsina State Transport Authority (KTSTA)}

Katsina State Transport Authority is a governmental and non-profitable Organization created to provide an affordable, safe, and comfortable transportation to the people of Katsina State and Nigeria at large. KTSTA like other sister transport Organization uses different category of buses in carrying out its operations. It was inherited from Kaduna State Transport Authority when the state was created in 1987 by the Military Administration of General Ibrahim Babangida Badamasi. And it serves as one of major means of transportation within the country. KTSTA render the following services: Inter State services; Intra State services; International Route (Katsina-Senegal (Qualaha)); and on Request (Hire): It requires no specific route. KSTA is located at Tashar Batsari road Katsina.

Katsina State transport authority (KTSTA) operates 52-seater Marcopolo 1721, 30-seater Fuso Rosa, 18-seater Toyota Hiace, and 30-seater Toyota Coaster. According to research and interview with the KTSTA officials, the Buses incur costs in four ways: fuel consumption, percentage parking levy, routine service and maintenance (repair). Furthermore, this study is limited to the first two services - inter and intra state services due to interest. These routes are as follows:

Inter States Routes Possible No of Buses:

Katsina-Abuja, Katsina-Kaduna, Katsina-Kano, Katsina-Sokoto, Katsina-Bauchi, KatsinaGombe,

Katsina-Minna, Katsina-Jos, and Katsina-Zaria 
Intra States Routes Possible No of Buses:

Katsina-Daura, Katsina-Funtua, Katsina-Malumfashi, Katsina-Dutsin-Ma, Katsina-Mani, Katsina-Kankia, Katsina-Batsari, Katsina-Jibia, and Katsina-Ingawa

The main objective of the study was to apply linear programming model to optimally allocate the available buses of the Transport Authority to the service routes. The simulation results will be compare to the existing traditional method of allocation to see which one gives optimal result for profit maximization. Abubakar et.al (2020) conducted a research on Yoghurt Production by ATS Multi-Concept Worldwide Ltd in Katsina State, Nigeria where they were able to identified and recommend to the company on the quantity of production of some categories of yoghurt to be produce for profit maximization. The work carried out by Nyor et al (2014) inspired us to conduct this research

\section{Sensitivity Analysis}

Sensitivity analysis is a technique used for determining how the independent variable values will impact a specific dependent variable under a given assumption(s). It helps the researcher, reader and policy makers to know how sensitive a model is to changes in the value of parameters of the model and to change in the structure of the model (Monika and Ashish, 2019). Meanwhile, Goyal et al (2017) stated that sensitivity analysis dictate how the uncertainty in the output, or sensitivity in as output of a mathematical model or a complex system, can be assigned to different sources of uncertainty in its inputs or to change in an input while keeping the other inputs constant.

\section{RESEARCH METHODOLOGY}

In this section, data were collected and transform into linear programming problem taking into consideration all the constraints. Below data were collected in October, 2020 from KTSTA headquarters which is located at Tashar Batsari Road, Katsina.

\section{Table 1: Data on Bus Routes}

\begin{tabular}{|c|c|c|c|c|c|c|c|c|}
\hline $\begin{array}{l}\mathrm{S} / \\
\mathrm{N}\end{array}$ & Route & $\begin{array}{l}\text { Frequency } \\
\text { of trip per } \\
\text { week }\end{array}$ & $\begin{array}{c}\text { Fuel } \\
\text { Consumpt } \\
\text { ion (Ltrs) } \\
\text { (PMS) }\end{array}$ & $\begin{array}{l}\text { Perce } \\
\text { ntage } \\
\text { Parki } \\
\text { ng } \\
\text { Levy }\end{array}$ & $\begin{array}{c}\text { No. of } \\
\text { Buses } \\
\text { Per } \\
\text { route } \\
\text { per Day }\end{array}$ & $\begin{array}{l}\text { Max No. } \\
\text { Of trips } \\
\text { per Bus } \\
\text { Per Day }\end{array}$ & $\begin{array}{l}\text { No. Of } \\
\text { hours } \\
\text { per half } \\
\text { Trip }\end{array}$ & $\begin{array}{l}\text { Transport } \\
\text { Fare per } \\
\text { Person (N) }\end{array}$ \\
\hline 1 & KATSINA-ABUJA & DAILY & 150 & 10 & 2 & 1 & 7 & 2,500 \\
\hline 2 & KATSINA-KADUNA & “ & 90 & $"$ & 3 & 1 & 4 & 1,600 \\
\hline 3 & KATSINA-KANO & “ & 50 & “ & 3 & 2 & 3 & 700 \\
\hline 4 & KATSINA-SOKOTO & “ & 150 & “ & 1 & 1 & 6 & 3,000 \\
\hline 5 & KATSINA-BAUCHI & “ & 150 & “ & 1 & 1 & 6 & 2,500 \\
\hline 6 & KATSINA-GOMBE & “ & 185 & “ & 1 & 1 & 8 & 3,500 \\
\hline 7 & KATSINA-MINNA & “ & 170 & “ & 1 & 1 & 7 & 3,500 \\
\hline 8 & KATSINA-JOS & “ & 150 & “ & 2 & 1 & 7 & 2,500 \\
\hline 9 & KATSINA-ZARIA & “ & 70 & $"$ & 3 & 1 & 3 & 1,200 \\
\hline 10 & KATSINA-DAURA & “ & 25 & “ & 4 & 3 & 0.5 & 250 \\
\hline 11 & KATSINA-FUNTUA & “ & 55 & “ & 2 & 2 & 1 & 600 \\
\hline 12 & $\begin{array}{c}\text { KATSINA- } \\
\text { MALUMFASHI }\end{array}$ & “ & 80 & “ & 4 & 5 & 1 & 500 \\
\hline 13 & KATSINA-DUTSINMA & “ & 20 & “ & 2 & 2 & 0.5 & 150 \\
\hline 14 & KATSINA-MANI & “ & 20 & " & 5 & 3 & 0.5 & 120 \\
\hline 15 & KATSINA-KANKIA & " & 15 & “ & 4 & 3 & 0.5 & 150 \\
\hline 16 & KATSINA-BATSARI & “ & 15 & “ & 2 & 4 & 0.5 & 100 \\
\hline 17 & KATSINA-JIBIA & “ & 15 & “ & 3 & 4 & 0.5 & 100 \\
\hline \multirow[t]{2}{*}{18} & KATSINA-INGAWA & “ & 25 & “ & 2 & 3 & 0.5 & 160 \\
\hline & TOTAL & & 1,435 & 180 & 45 & 39 & 56.5 & 23,130 \\
\hline
\end{tabular}


Table 2: Data on Bus Service

\begin{tabular}{ccc}
\hline S/N & Required Service Items & Amount (₹) \\
\hline 1 & Oil filter & 500 \\
2 & 5-litre Engine oil & 4200 \\
3 & Oil treatment & 600 \\
& Total & 5300
\end{tabular}

Note: Buses in KTSTA are serviced twice in a month, which is after 15 days

Table 3: Data on bus repair/maintenance

\begin{tabular}{cccc}
\hline S/N & Repair/maintenance items & Cost (N) & Duration it lasts \\
\hline 1 & Tyre & 112,000 & 5 months \\
2 & Front bearing & 14,000 & 6 months \\
3 & Break disk & 6,000 & 1 year \\
4 & Break pad & 2,000 & 1 month \\
5 & Break lining & 4,000 & 1 month \\
6 & Car battery & 17,000 & 1 year \\
7 & Shocks filling & 1,500 & 3 months \\
8 & Sparkling plugs & 3,000 & 1 year \\
9 & Fuel pump & 3,500 & 1 year \\
10 & Release bearing & 3,000 & 1 year \\
& Total & 166,000 & \\
\hline
\end{tabular}

\section{MODEL CONSTRUCTION}

In this section, data obtained at KTSTA headquarter were used to formulate the model and subsequently solve the model

Table 4: Daily cost of Bus service

\begin{tabular}{ccccc}
\hline S/N & Required Service Items & $\begin{array}{c}\text { Amount Per } \\
\text { 15 Days (N) }\end{array}$ & $\begin{array}{c}\text { Amount Per } \\
\text { Month (N) }\end{array}$ & $\begin{array}{c}\text { Daily Service cost } \\
\text { per bus (N) }\end{array}$ \\
\hline 1 & Oil filter & 500 & 1000 & $1000 \div 30=33$ \\
2 & 5 -litre Engine oil & 4200 & 8400 & $8400 \div 30=280$ \\
3 & Oil treatment & 600 & 1200 & $1200 \div 30=40$ \\
& Total & 5300 & 10,600 & 353
\end{tabular}

Note: Buses in KTSTA are serviced twice in a month. This means that a bus in KTSTA consumes $\$ 10,600$ in a month. Dividing service amount per month by 30 gives us $\$ 353$ as the cost of servicing a bus in a day 
Table 5: Daily cost of repair/maintenance

\begin{tabular}{lccccc}
\hline S/N & Repair/maintenance items & Cost (N) & $\begin{array}{c}\text { Duration it } \\
\text { lasts }\end{array}$ & $\begin{array}{c}\text { Duration in } \\
\text { days }\end{array}$ & $\begin{array}{c}\text { Cost per } \\
\text { day (N) }\end{array}$ \\
\hline 1 & Tyre & 112,000 & 5 months & $5 \times 30=150$ & 747 \\
2 & Front bearing & 14,000 & 6 months & $6 \times 30=180$ & 78 \\
3 & Break disk & 6,000 & 1 year & $12 \times 30=360$ & 17 \\
4 & Break pad & 2,000 & 1 month & $30 \times 1=30$ & 67 \\
5 & Break lining & 4,000 & 1 month & $1 \times 30=30$ & 133 \\
6 & Car battery & 17,000 & 1 year & $12 \times 30=360$ & 47 \\
7 & Shocks filling & 1,500 & 3 months & $3 \times 30=90$ & 17 \\
8 & Sparkling plugs & 3,000 & 1 year & $12 \times 30=360$ & 08 \\
9 & Fuel pump & 3,500 & 1 year & $12 \times 30=360$ & 10 \\
10 & Release bearing & 3,000 & 1 year & $12 \times 360=360$ & 08 \\
& Total & 166,000 & & & 1,132 \\
\hline
\end{tabular}

Table 6: Daily contribution per bus

\begin{tabular}{|c|c|c|c|c|c|c|c|c|c|c|c|c|c|}
\hline $\begin{array}{c}\text { Fuel } \\
\text { consu } \\
\text { mptio } \\
\text { n per } \\
\text { bus } \\
\text { (ltrs) }\end{array}$ & $\begin{array}{c}\text { Fuel } \\
\text { contributi } \\
\text { on per } \\
\text { bus (N) }\end{array}$ & $\begin{array}{l}\text { Perc } \\
\text { enta } \\
\text { ge } \\
\text { park } \\
\text { ing } \\
\text { levy } \\
\text { per } \\
\text { bus } \\
(\%)\end{array}$ & $\begin{array}{c}\text { Monetar } \\
\text { y } \\
\text { parking } \\
\text { levy (N) }\end{array}$ & $\begin{array}{l}\text { No. of } \\
\text { buses } \\
\text { per } \\
\text { route } \\
\text { per } \\
\text { day }\end{array}$ & $\begin{array}{l}\text { Max. } \\
\text { no. of } \\
\text { buses } \\
\text { per } \\
\text { route } \\
\text { per } \\
\text { day }\end{array}$ & $\begin{array}{c}\text { Equiv } \\
\text { alent } \\
\text { no. of } \\
\text { buses } \\
\text { per } \\
\text { route } \\
\text { per } \\
\text { day }\end{array}$ & $\begin{array}{l}\text { No. } \\
\text { of } \\
\text { hour } \\
\text { s per } \\
\text { half } \\
\text { trip }\end{array}$ & $\begin{array}{l}\text { Transport } \\
\text { fare per } \\
\text { person }\end{array}$ & $\begin{array}{l}\text { Daily } \\
\text { cost of a } \\
\text { bus } \\
\text { service }\end{array}$ & $\begin{array}{l}\text { Daily } \\
\text { cost of a } \\
\text { bus } \\
\text { repair/ } \\
\text { mainten } \\
\text { ance }\end{array}$ & $\begin{array}{l}\text { Return per } \\
\text { bus per trip } \\
\text { (丹) }\end{array}$ & $\begin{array}{l}\text { Daily total } \\
\text { expenditure } \\
\text { per bus }(\mathrm{A})\end{array}$ & $\begin{array}{c}\text { Daily } \\
\text { contribution } \\
\text { per bus ( } \mathrm{N} \text { ) }\end{array}$ \\
\hline 150 & 24,750 & 10 & 3,250 & 2 & 1 & 2 & 7 & 2,500 & 353 & 1,132 & 65,000 & 29,480 & 35,515 \\
\hline 90 & 14,850 & 10 & 2,080 & 3 & 1 & 3 & 4 & 1,600 & 353 & 1,132 & 41,600 & 18,415 & 23,185 \\
\hline 50 & 8,250 & 10 & 910 & 3 & 2 & 6 & 3 & 700 & 353 & 1,132 & 18,200 & 10,645 & 7,555 \\
\hline 150 & 24,750 & 10 & 3,000 & 1 & 1 & 1 & 6 & 3,000 & 353 & 1,132 & 60,000 & 29,235 & 30,765 \\
\hline 150 & 24,750 & 10 & 3,250 & 1 & 1 & 1 & 6 & 2,500 & 353 & 1,132 & 65,000 & 26,485 & 35,515 \\
\hline 185 & 30,525 & 10 & 4,550 & 1 & 1 & 1 & 8 & 3,500 & 353 & 1,132 & 91,000 & 36,560 & 54,440 \\
\hline 170 & 28,050 & 10 & 4,550 & 1 & 1 & 1 & 7 & 3,500 & 353 & 1,132 & 91,000 & 34,085 & 56,915 \\
\hline 150 & 24,750 & 10 & 3,250 & 2 & 1 & 2 & 7 & 2,500 & 353 & 1,132 & 65,000 & 29,485 & 33,512 \\
\hline 70 & 11,550 & 10 & 1,560 & 3 & 1 & 3 & 3 & 1,200 & 353 & 1,132 & 31,200 & 14,595 & 16,605 \\
\hline 25 & 4,125 & 10 & 325 & 4 & 3 & 12 & 0.5 & 250 & 353 & 1,132 & 9,000 & 5,935 & 3,051 \\
\hline 55 & 9,165 & 10 & 780 & 2 & 2 & 4 & 1 & 600 & 353 & 1,132 & 21,600 & 11,430 & 10,170 \\
\hline 80 & 13,200 & 10 & 650 & 4 & 5 & 20 & 1 & 500 & 353 & 1,132 & 18,000 & 15,335 & 2,665 \\
\hline 20 & 3,300 & 10 & 195 & 2 & 2 & 4 & 0.5 & 150 & 353 & 1,132 & 5,400 & 4,980 & 420 \\
\hline 15 & 2,475 & 10 & 165 & 5 & 3 & 15 & 0.5 & 120 & 353 & 1,132 & 4,320 & 4,116 & 204 \\
\hline 20 & 3,300 & 10 & 195 & 4 & 3 & 12 & 0.5 & 150 & 353 & 1,132 & 5,400 & 4,980 & 420 \\
\hline 15 & 2,475 & 10 & 130 & 2 & 4 & 8 & 0.5 & 100 & 353 & 1,132 & 3,600 & 4,090 & -490 \\
\hline 15 & 2,475 & 10 & 130 & 3 & 4 & 12 & 0.5 & 100 & 353 & 1,132 & 3,600 & 4,090 & -490 \\
\hline 25 & 4,125 & 10 & 208 & 2 & 3 & 6 & 0.5 & 160 & 353 & 1,132 & 5,760 & 5,818 & -58 \\
\hline 1,435 & 236,865 & 180 & 29,169 & 45 & 39 & 113 & 56.5 & 23,130 & 6,354 & 20,376 & 604,680 & 289,764 & 311,899 \\
\hline
\end{tabular}

Note:

- 'Daily cost of service per bus' and 'daily cost of repair/maintenance per bus' are obtained in tables 4 and 5 respectively.

- 'Equivalent number of buses per route' is obtained by multiplying 'Number of buses per route' by 'number of trips per day'. Remember, a trip means to and fro Katsina.

- 'Return per bus per trip' is obtained by multiplying 'transport fare' per passenger by 2 
- 'Total expenditure per bus' is obtained by adding 'fuel consumption', Monetary parking levy', 'daily service per bus' and 'daily repair/maintenance per bus'.

\section{Table 7: Daily contribution per route}

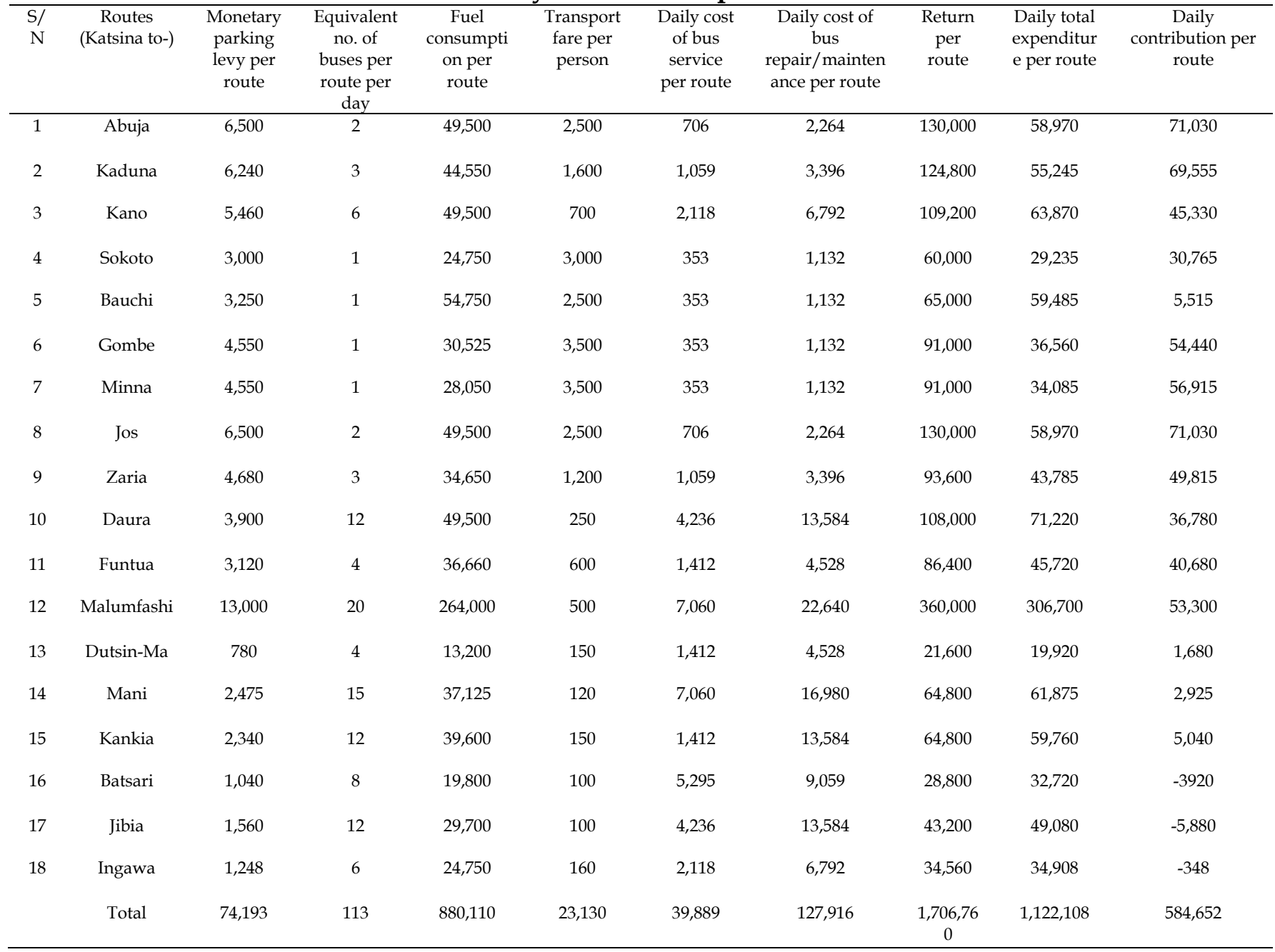

\section{KTSTA Problem Formulation}

The Problem is Formulated using the information on Table 6. The problem is formulated under the assumption that all the 113 buses that commute intra and inter states routes were working daily optimally. Based on the interview with KTSTA, availability of passengers and the number of other transport services plying the same routes, among other factors, determine the number of buses that KTSTA can assign to these routes. The following shows the possible number of buses that can be scheduled to routes:

Table 8: Possible number of buses

\begin{tabular}{|c|c|c|c|}
\hline Inter- State Routes & $\begin{array}{l}\text { Possible number of } \\
\text { Buses }\end{array}$ & Intra-State Routes & $\begin{array}{l}\begin{array}{l}\text { Possible number of } \\
\text { buses }\end{array} \\
\end{array}$ \\
\hline Katsina-Abuja & $2-3$ & Katsina-Daura & 12 \\
\hline Katsina-Kaduna & 3-4 & Katsina-Funtua & 4 \\
\hline Katsina-Kano & 6 & Katsina-Malumfashi & 20 \\
\hline Katsina-Sokoto & 1 & Katsina-Dutsin-Ma & 4 \\
\hline Katsina-Bauchi & 1 & Katsina-Mani & 15 \\
\hline Katsina-Gombe & 1 & Katsina-Kankia & 12 \\
\hline Katsina-Minna & 1 & Katsina-Batsari & 8 \\
\hline Katsina-Jos & $2-3$ & Katsina-Jibia & 12 \\
\hline
\end{tabular}


Katsina-Zaria $\quad 3-4 \quad$ Katsina-Ingawa $\quad 6$

Noted that the allocation must not exceed 113 buses available for intra and inter states services. Below is formulated problem

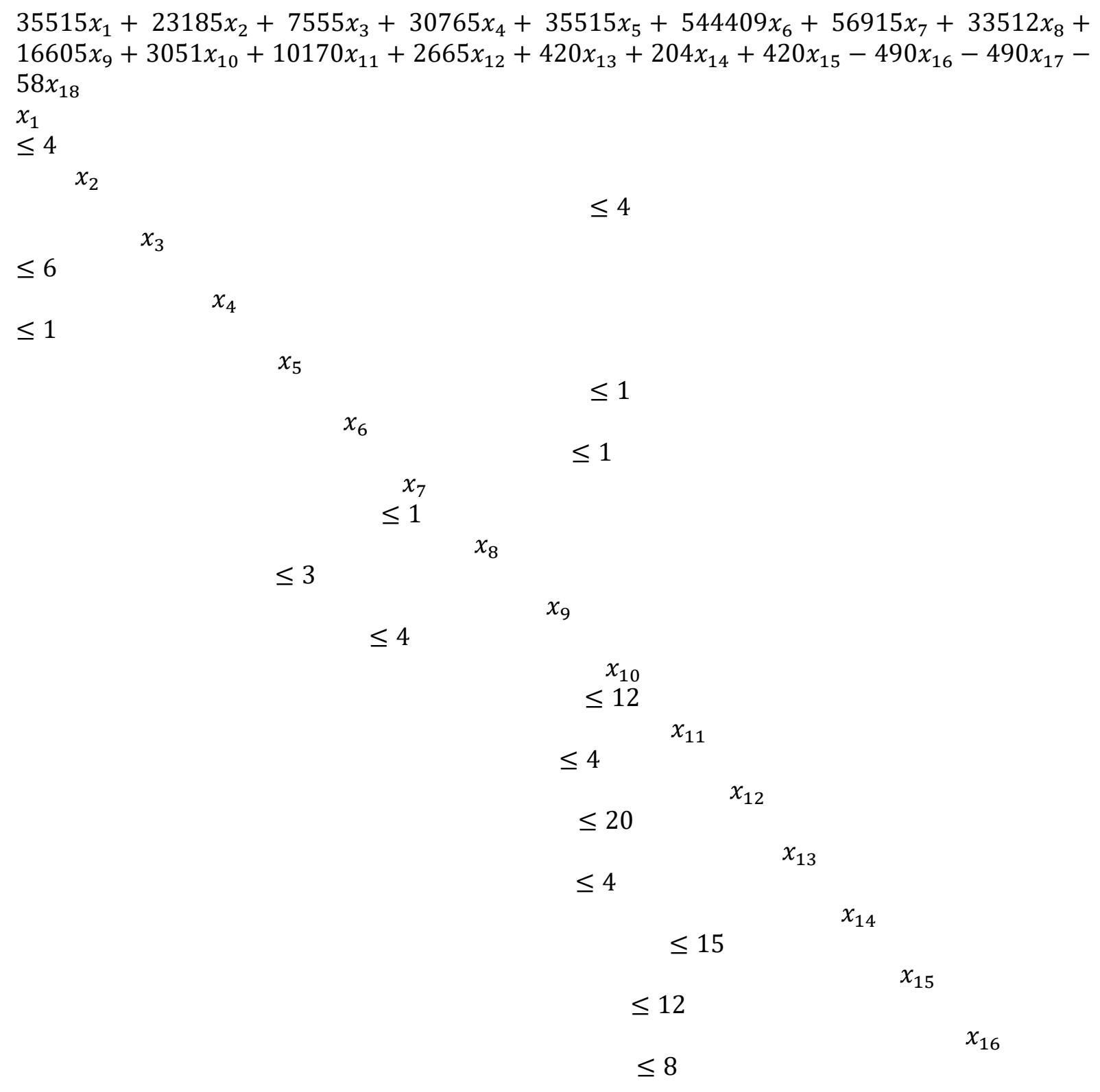

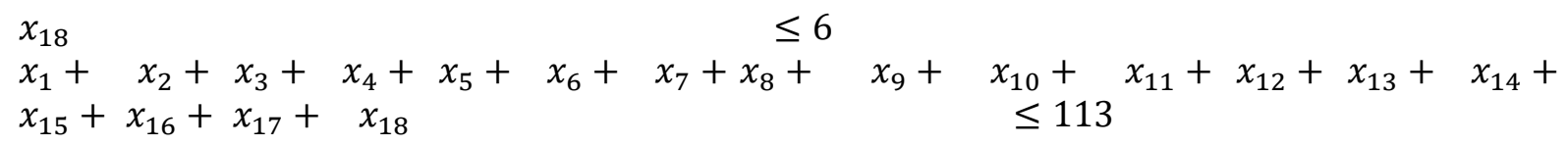

\section{NUMERICAL RESULTS AND DISCUSSION}

In this section, result of the problem formulated will be analyze and discuss. The formulated problem was solved using TORA - computer software used in solving Linear Programming problems. The software was developed by Hamdy Taha (2002 edition). The software was run HP Laptop with processor 1.3GHz, 4.00 GB RAM and 64-bit operating system. 
Linear Programming Application in optimal allocation of Buses to Inter and Intra State Routes from Katsina State Transport Authority Service, Nigeria

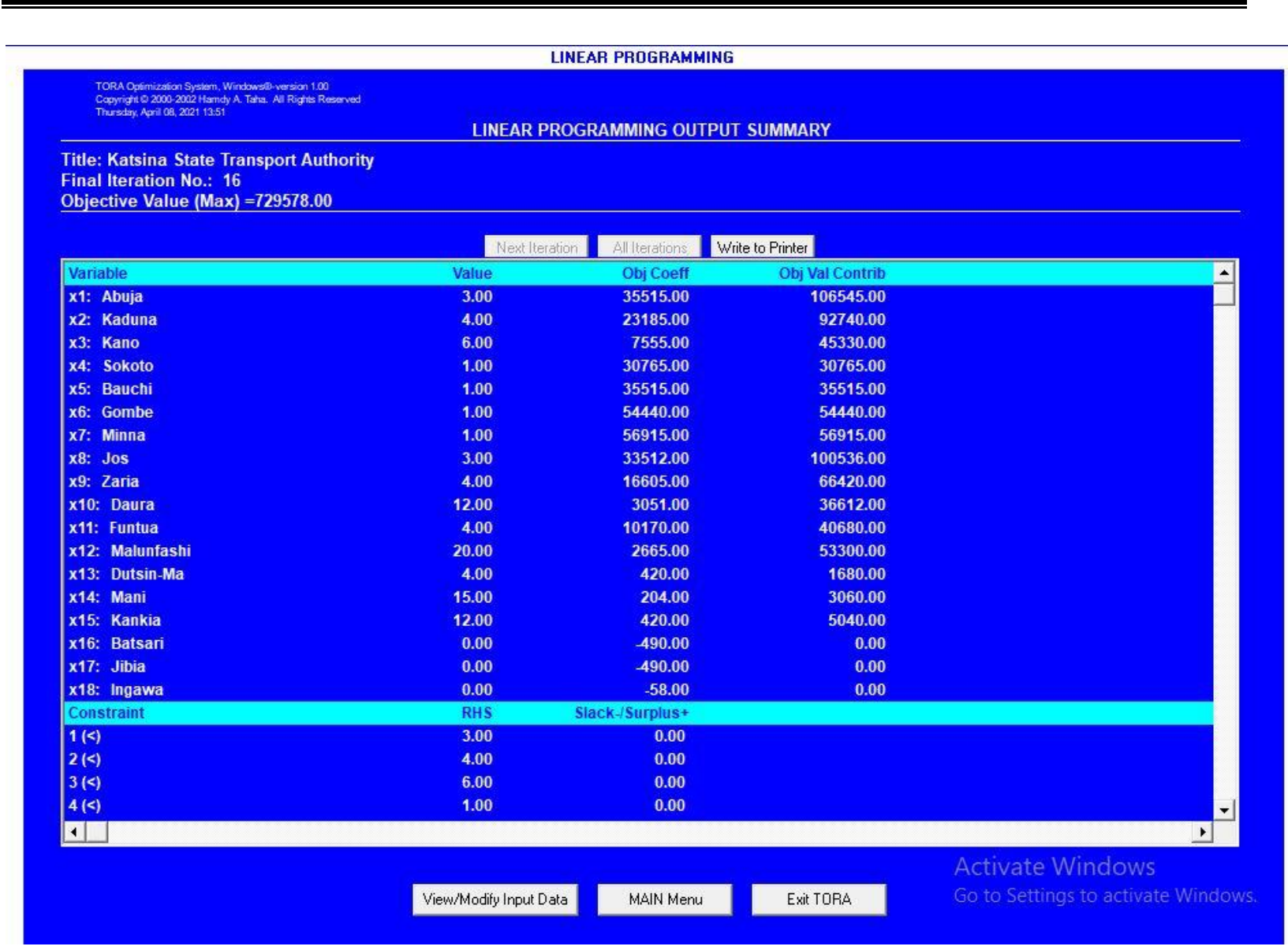

Figure1. Linear Programming Output Summary

\begin{tabular}{|lrr|}
\hline Constraint & RHS & Slack-Surplus+ \\
\hline $1(<)$ & 3.00 & 0.00 \\
$2(<)$ & 4.00 & 0.00 \\
$3(<)$ & 6.00 & 0.00 \\
$4(<)$ & 1.00 & 0.00 \\
$5(<)$ & 1.00 & 0.00 \\
$6(<)$ & 1.00 & 0.00 \\
$7(<)$ & 1.00 & 0.00 \\
$8(<)$ & 3.00 & 0.00 \\
$9(<)$ & 4.00 & 0.00 \\
$10(<)$ & 12.00 & 0.00 \\
$11(<)$ & 4.00 & 0.00 \\
$12(<)$ & 20.00 & 0.00 \\
$13(<)$ & 4.00 & 0.00 \\
$14(<)$ & 15.00 & 0.00 \\
$15(<)$ & 12.00 & 0.00 \\
$16(<)$ & 8.00 & 8.00 \\
$17(<)$ & 12.00 & $12.00-$ \\
$18(<)$ & 6.00 & $6.00-$ \\
$19(<)$ & 113.00 & $22.00-$ \\
\hline
\end{tabular}

Figure2. Linear Programming Output Summary

Figures 1 and 2 above, variable is the name of the route. For example, $x_{1}$ represents Katsina to Abuja route. Value is the number of buses to be allowed to ply Katsina-Abuja. Objective coefficient is the contribution made per bus. Objective value contribution is the result of multiplying 'value' and the 'objective coefficient'. $x_{16}, x_{17}$, and $x_{18}$ are zero because the buses are running at lost, therefore, no bus is recommend to be allocate to those routes. The

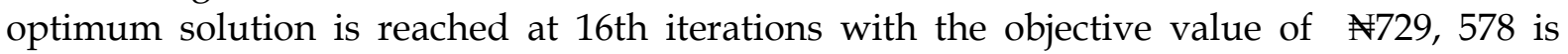
obtained as can be seen on TORA window. 


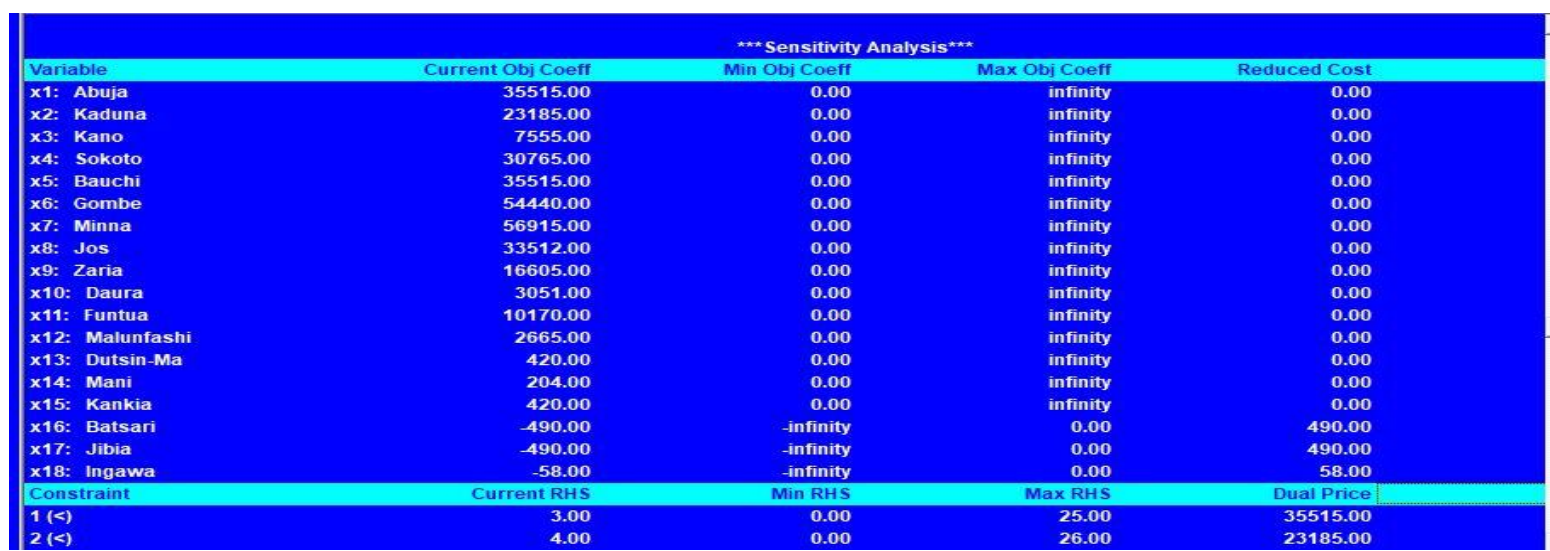

Figure3. Linear Programming Output Summary

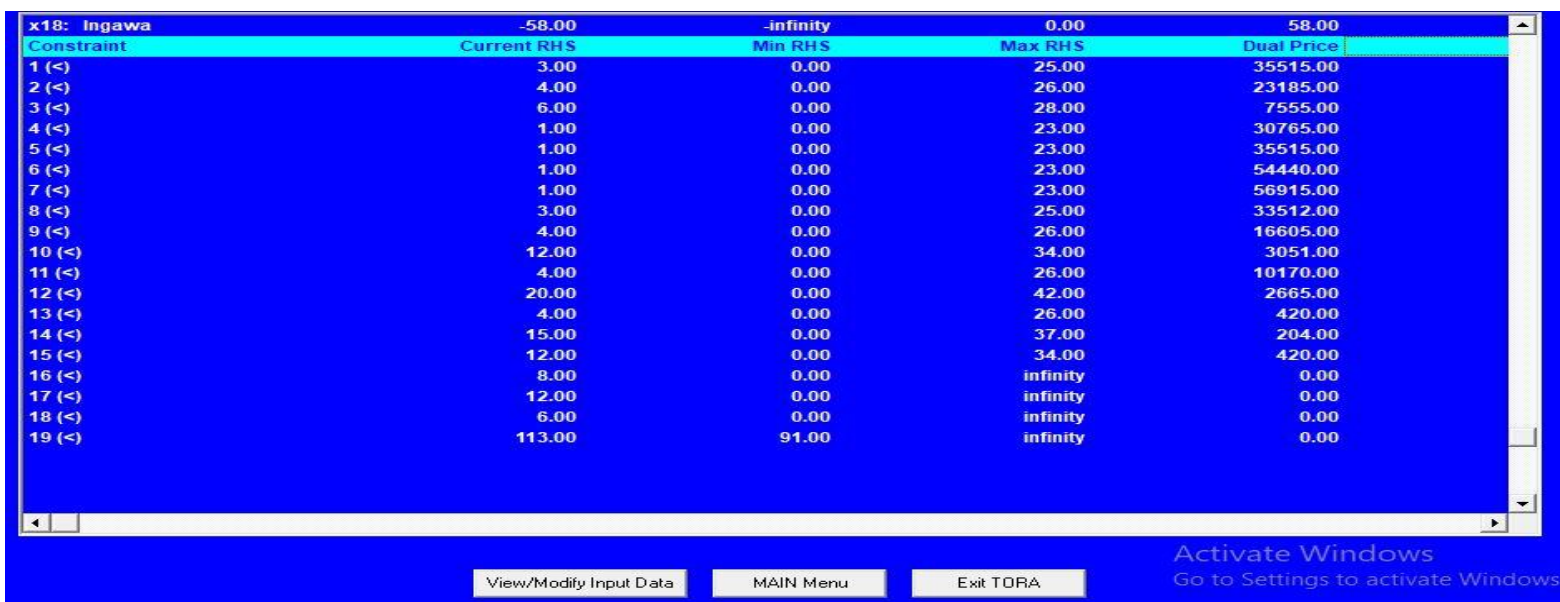

Figure4. Linear Programming Output Summary

Figures 3 and 4 present the sensitivity analysis report. The sensitivity analysis was carried out to know the extent to which any of the data (that is, the per unit profit of the variable) of the company can change without affecting the primal solution. The result of the sensitivity analysis also showed the dual price also known as the shadow price enable the company to know the cost of acquiring an additional unit of any of their resources in case there is a need.

Table 9: Current Schedule versus recommended schedules

\begin{tabular}{|c|c|c|c|c|c|}
\hline $\begin{array}{l}\text { Inter- State } \\
\text { Routes }\end{array}$ & $\begin{array}{c}\text { KTSTA } \\
\text { current } \\
\text { schedule }\end{array}$ & $\begin{array}{l}\text { Recommended } \\
\text { schedule }\end{array}$ & $\begin{array}{c}\text { Intra-State } \\
\text { Routes }\end{array}$ & $\begin{array}{c}\text { KTSTA } \\
\text { current } \\
\text { schedule }\end{array}$ & $\begin{array}{l}\text { Recommended } \\
\text { schedule }\end{array}$ \\
\hline Katsina-Abuja & 2 & 3 & Katsina-Daura & 12 & 12 \\
\hline $\begin{array}{l}\text { Katsina- } \\
\text { Kaduna }\end{array}$ & 3 & 4 & Katsina-Funtua & 4 & 4 \\
\hline Katsina-Kano & 6 & 6 & $\begin{array}{l}\text { Katsina- } \\
\text { Malumfashi }\end{array}$ & 20 & 20 \\
\hline $\begin{array}{l}\text { Katsina- } \\
\text { Sokoto }\end{array}$ & 1 & 1 & $\begin{array}{c}\text { Katsina-Dutsin- } \\
\mathrm{Ma}\end{array}$ & 4 & 4 \\
\hline $\begin{array}{l}\text { Katsina- } \\
\text { Bauchi }\end{array}$ & 1 & 1 & Katsina-Mani & 15 & 15 \\
\hline $\begin{array}{l}\text { Katsina- } \\
\text { Gombe }\end{array}$ & 1 & 1 & Katsina-Kankia & 12 & 12 \\
\hline $\begin{array}{l}\text { Katsina- } \\
\text { Minna }\end{array}$ & 1 & 1 & Katsina-Batsari & 8 & 0 \\
\hline Katsina-Jos & 2 & 3 & Katsina-Jibia & 12 & 0 \\
\hline Katsina-Zaria & 3 & 4 & Katsina-Ingawa & 6 & 0 \\
\hline
\end{tabular}




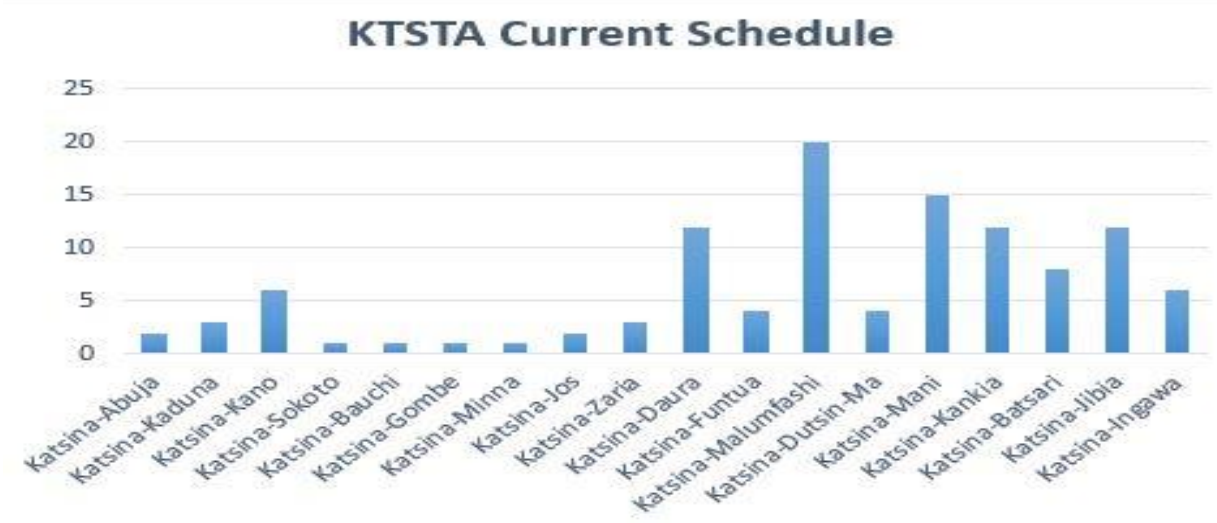

Figure 5: KTSA current schedule

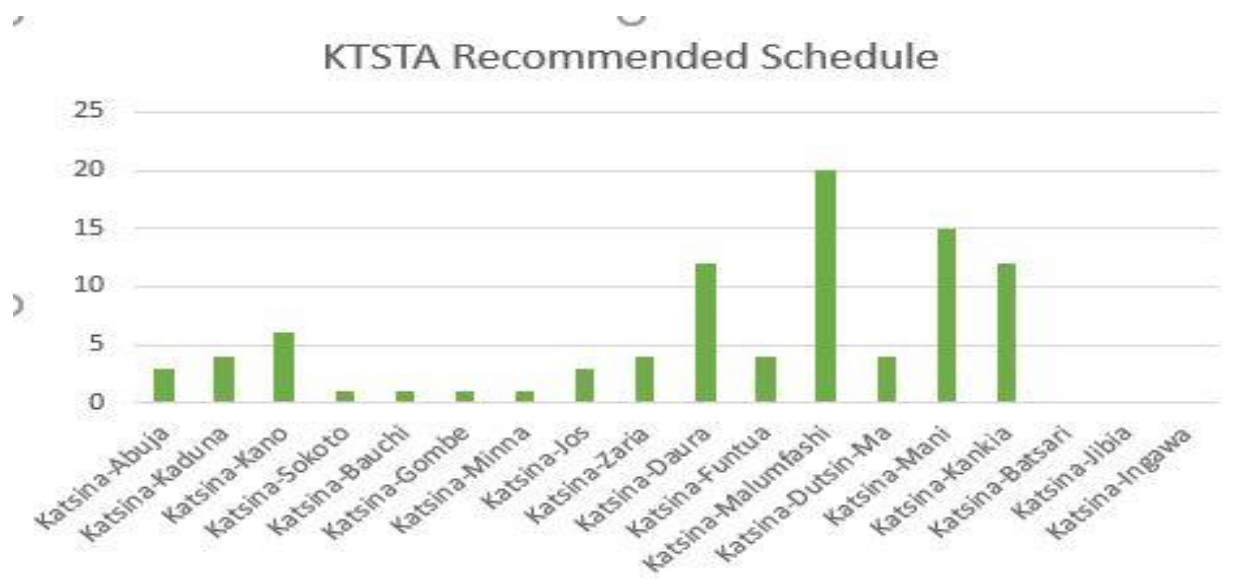

Figure 6: KTSA recommended schedule

Figures 5 and 6 show the current and recommend schedule for the KTSTA respectively. It is observed from the Figure 6 that in the recommend chart, Katsina to Batsari, Katsina to Jibia and Katsina to Ingawa are zeros, which implies no allocation made for these routes in the recommendation schedule as against 8,12 and 6 respectively in the current intuitive way of scheduling. This is justifiable because KTSTA is recording losses plying those routes.

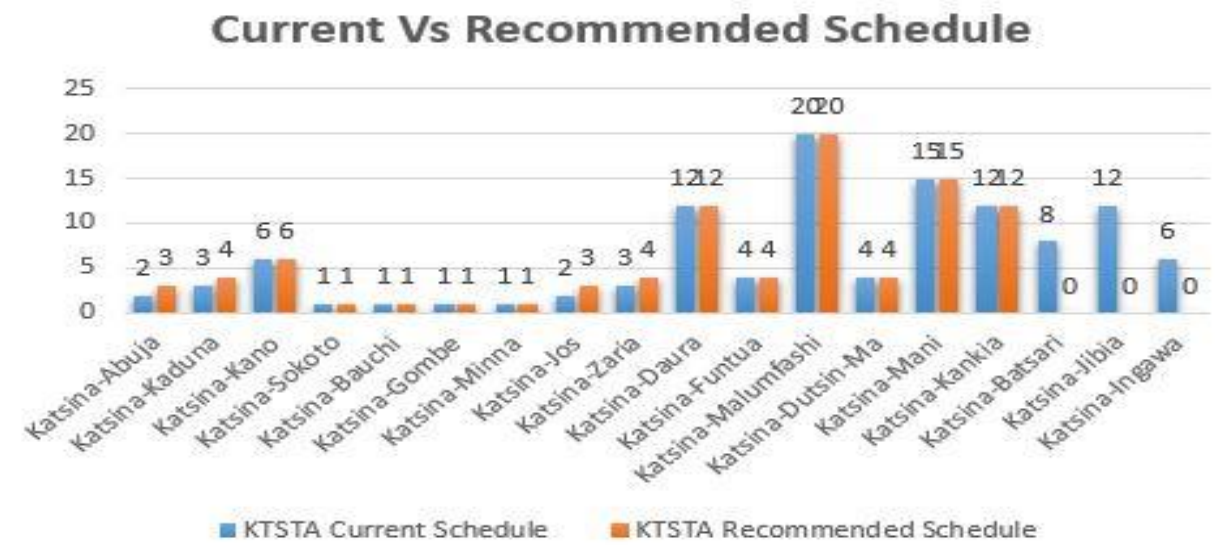

Figure 7: KTSTA current versus recommended schedules 


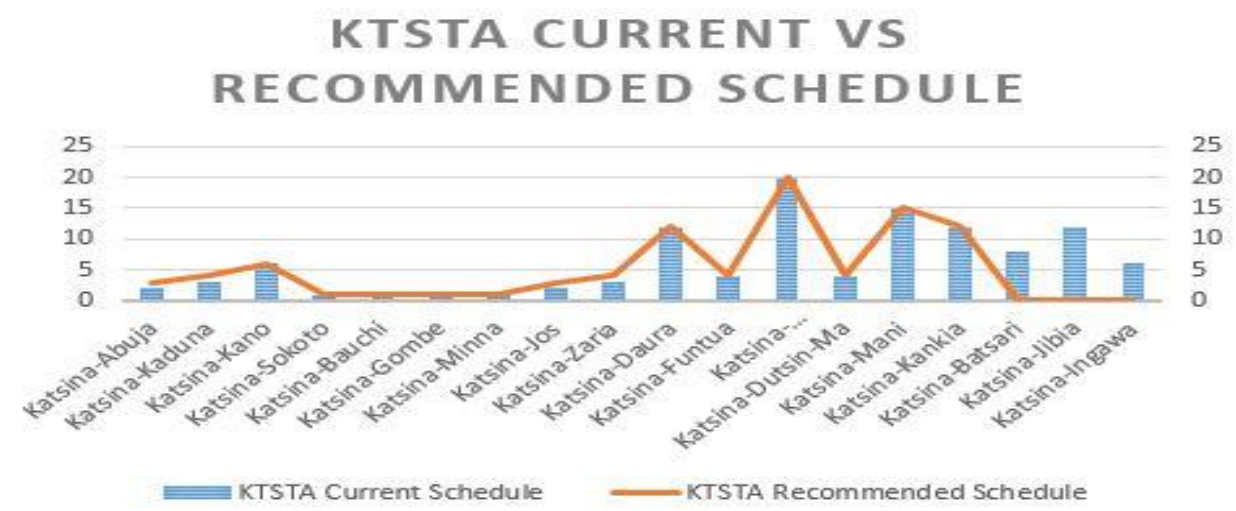

Figure 8: KTSTA current Versus recommended schedules

Figures 7 and 8 represent the combination of current and recommendation charts for clearer illustration of the current and recommendation schedules. Recommendation suggests either increase or decrease or no change in the current intuitive way of scheduling for optimum profit to the organization. Recommendation chart suggest increase in allocation of buses in the following routes: Katsina-Abuja from 2 to 3, Katsina -Kaduna from 3 to 4, Katsina- Jos from 2 to 3, and Katsina -Zaria from 3 to 4 for better profit to KTSTA. While no change in the allocation of buses was made to Katsina - Kano, Katsina -Sokoto, Katsina- Bauchi, KatsinaGombe, Katsina-Minna, Katsina- Daura, Katsina-Funtua, Katsina- Malumfashi, KatsinaDutsin-Ma, Katsina-Mani, and Katsina-Kankia. However, recommendation suggest drastic decrease in the allocation buses, in fact zero allocation in the followings routes: KatsinaBatsari, Katsina -Jibia and Katsina-Ingawa. This zero allocation is due to losses recorded on the routes as shown in Table 6.

\section{CONCLUSION}

The current KTSTA schedule seen in Table 7 yields a daily contribution of $\$ 584,652.00$. Our recommended schedule will yield \$729,578.00 when implemented. Furthermore, consideration of sensitivity analysis will yield more profit from the recommended solution obtained when more resources are deployed to the appropriate routes. The organization will be getting additional $\$ 144,926.00$ daily which translate to $24.8 \%$ daily profit increase and over $\$ 4,000,000.00$ monthly when implemented. Especially, at this current unstable economic situation, this recommendation will help in boosting the state internally generated revenue (IGR).

\section{REFERENCES}

Abubakar, J., Abdullahi, I., Usman, S., Danjuma, N. \& Agaie, B. G. (2020). Linear Programming as Decision Making Tool for Optimal Production:A Case Study of Yoghurt Production by ATS Multi-Concept Worldwide Ltd in Katsina State, Nigeria. FUDMA Journal of Sciences (FJS), 4( 1), 750 - 755

Bertsimas, D., \& Tsitsiklis, J.N. (1997). Introduction to linear optimization. Belmont, MA: Athena Scientific. 6, 479-530

Dantzig G.B. (1963). Linear Programming and Extension. Priceton University Press.

Dass, H.K. (2013). Advance Engineering Mathematics $21^{\text {st }}$ Ed. New Delhi: S. Chand \& Company PVT. Ltd. en.m.wikibooks.org/wiki/Operations_Research/Sensitivity_analysis

Fang, S.C., \& Puthenpura, S. (1993). Linear optimization and extensions: theory and algorithms. Practice-Hall, Inc. 
Hiller, F.S., Lieberman G.J., \& Liebman G. (1995). Introduction to Operation research. New York: McGraw-Hill.

Lieberman, G.J.(2001). Introduction to operation research. Boston: McGraw-Hill Higher eduction.

Lucey, T. (2002). Quantitative Techniques: Book power. ELST edition.

Kanu, S.I. Ozurumbu, B.A, \& Emerole I.C.(2014). Application of Linear Programming Techniques to Practical decision making. Mathematical theory and modeling. Vol4(9): 100-110.

Ng, K.K.H., Lee, C.K., Chan, F.T., \& Lv, Y. (2018). Review on meta-heuristics approaches for airside operation research. Applied soft computing, 66, 104-133

Nyor, N., Joseph, O.O, \& Kamilu, R. (2014). Application of Linear Programming in Modeling the Allocation of Buses to Routes in a Transport Service Authority. Universal Journal of Applied Mathematics 2(3): 125-135.

Salimifard, K., Shahbandarzadeh, H., \& Raeesi, R. (2012). Green transportation and the role of operation research. In int. Conf. Traffic Transp. Eng. 26, 74-79 